\title{
PROGRAM STUDI HUBUNGAN INTERNASIONAL: BAGAIMANA MENGGAPAI KOMPETENSI DAN AKTUALITAS?
}

\author{
V.L. Sinta Herindrasti \\ herindrasti@yahoo.com
}

\begin{abstract}
Integration and interdependent among nations has already creating the new world for the Indonesian youth. The on going radical and rapid changing must be anticipated through the mind set changing in order to understand deeply how the different sectors of society have their own logic of operation and interests. Besides mastering on the basic theoretical concepts, the International Relations student must also be equipped with the strong soft and hard skills, which are needed to be involved in the global environment so that International Relations Study majoring in various certain fields of study will become a part of efforts to achieve international competence and to answer further more important question, how can we create a transformative social knowledge for our own nation development?
\end{abstract}

Keywords: Globalization, Linkage, Soft skill, Hard skill, International competence, Transformative social knowledge

\section{Pendahuluan}

Berbagai headline surat kabar yang memprihatinkan mengenai dunia pendidikan di Indonesia telah "mengepung" dan meresahkan kita sebagai insan yang mencoba membaktikan diri di dunia perguruan tinggi. Betapa tidak. "Ilmuwan Indonesia Diincar. Anggaran Penelitian Cuma Sekitar 0,3 Persen dari APBN" (Kompas, 24 Oktober 2011), "Negeri ini Tidak Nyaman bagi Peneliti"(Kompas, 24 Oktober 2011), "Potensi yang Terlalaikan", (Tajuk Rencana, Kompas 25 Oktober 2011), "Kesejahteraan Ilmuwan: Tak Ada Rencana Naikkan Gaji Peneliti” (Kompas, 27 Oktober 2011), "Culture of Bullying Grips Jakarta School" (The Jakarta Post, October 28, 2011), "RI's Education Development Index Drops" (The Jakarta Post, October 31, 2011), "Key Problem of Education in RI: Teacher Centralization (The JP, October 31, 2011), dan seterusnya dan sebagainya. Apa yang salah dengan manajemen pendidikan kita? Mengapa tidak ada suatu visi nasional yang jelas dengan parameter-parameter yang terukur? Mengapa para pelaksana di tingkat operasional pun mengalami disorientasi arah pendidikan? Masih segudang pertanyaan mengganjal yang untuk mencari jawaban memuaskan barangkali dibutuhkan analisis berbulan-bulan.

Mengalihkan pandangan dari fenomena makro, barangkali lebih realistis kalau kita menengok ke fenomena mikro yang lebih mendasar, yaitu program 
studi. Salah satu kendala dalam mengevaluasi diri sendiri adalah umumnya kita "sudah merasa tahu" ilmu kita sehingga agak sulit mengambil jarak dan bersikap obyektif. Tulisan ini sekedar catatan kecil bagi pelaksanaan program studi Hubungan Internasional di tengah jaman yang terus bergerak dan berubah, baik perubahan yang berkaitan langsung dengan Ilmu Hubungan Internasional maupun yang tidak langsung.

\section{Bagaimana Memahami Studi Hubungan Internasional?}

Studi Hubungan Internasional sebenarnya adalah salah studi yang paling muda akan tetapi justru studi yang mengalami perkembangan paling cepat. Sebagai pendatang baru, kira-kira baru pada tahun 1930-an (awal abad 20) mulai dengan kegiatan penelitian dan pengkajian akademis. Minat yang besar terhadap fenomena Internasional serta peristiwa besar yang sangat berpengaruh terhadap perkembangan politik Internasional, seperti Perang Dunia I merupakan faktor utama perkembangan studi Hubungan Internasional. ${ }^{1}$ Istilah International Relations menurut J. Frankel (1988) diciptakan oleh Jeremy Bentham ${ }^{2}$ meskipun sejarah hubungan internasional itu sendiri dapat di telusur balik hingga ribuan tahun yang lalu. Hubungan Internasional atau IR sering juga disebut International Studies (IS) adalah hubungan antar negara, termasuk peran IGO (Intergovernmental Organizations), INGO (International Non-governmental Organizations), NGO (Non-governmental Organizations) dan MNC (Multinational Corporations), juga sebagai bidang studi yang bersifat akademis ataupun kebijakan publik (policy), baik yang normatif maupun positif. ${ }^{3}$ Akan tetapi dalam perkembangannya, ruang lingkup Hubungan Internasional menjadi sangat luas, tidak hanya mencakup filsafat, hukum dan sejarah saja - sebagai disiplin yang pada awalnya bertanggungjawab mengajarkan hubungan internasional - tetapi meliputi berbagai aspek keilmuan lain, seperti ekonomi, geografi, sosiologi, antropologi, psikhologi, studi jender, studi kultural, teknologi informasi, dan lain-lain dan merambah berbagai isu yang lebih kontemporer selain "perang" dan "damai" yang dianggap isu klasik --, seperti globalisasi/"global village", "the rise of the rest" atau munculnya kekuatan baru (China, India, Brazil), keamanan internasional, pembangunan berkelanjutan, ekologi/kerusakan lingkungan, energi, keuangan global, pembatasan nuklir, hak asasi manusia, perang informasi, ruang angkasa dan sebagainya. Itulah mengapa sifat interdisipliner dari studi Hubungan Internasional memungkinkan kecenderungan, penekanan dan orientasi pada suatu aspek dan disiplin tertentu, entah politik, ekonomi atau hukum. Berbagai orientasi tersebut hendaknya dilihat sebagai sumbangan yang saling melengkapi dan memperkaya

${ }^{1}$ Lih al R. Soeprato, Hubungan Internasional: Sistem, Interaksi dan Perilaku. Jakarta: PT RajaGrafindo Persada, 1997. Hal 11-12. P. Anthonius Sitepu, Studi Hubungan Internasional. Yogyakarta: Graha Ilmu, 2011. Hal. 9-18.

2 Lihat lebih jauh http://en.wikipedia.org/wiki/Jeremy_Bentham. Seorang filsuf utilitarianisme asal Inggris, juga seorang pembaharu moral dan sosial. Teoritisi utama di bidang filsafat hukum sangat berpengaruh terhadap ide kesejahteraan (welfarism).

${ }^{3}$ Lihat al http://en.wikipedia.org/wiki/International_relations 
Hubungan Internasional (sebagai kekayaan intelektual) bukan sebagai pemecah belah yang justru memiskinkan ilmu Hubungan Internasional.

Dalam kaitannya dengan kecepatan perubahan konteks regional dan internasional dengan berbagai momen puncaknya, misalnya keruntuhan Uni Soviet (1991), Integrasi Uni Eropa (2007), percepatan globalisasi (1980-an), revolusi demokrasi di berbagai negara (2000); membuat ilmu Hubungan Internasional harus "berkejaran" dengan waktu untuk tidak hanya sampai pada "menjelaskan" sesuatu yang sudah terjadi namun juga membangun aspek konseptual teoritis. Sebagai contoh sebagian teori HI yang dikembangkan selama 40 tahun terakhir amat dipengaruhi oleh konteks Internasional dan peristiwa nyata persaingan dan perang dingin Amerika Serikat - Uni Soviet (1947-1990) dengan mandala persaingan berpusat di Eropa. ${ }^{4}$ Dengan sendirinya bagian besar pemikiran dan teori selama kurun waktu itu mengulas pasang surut hubungan kedua negara, dampaknya terhadap kawasan lain, polarisasi yang terjadi serta perimbangan kekuatan militer kedua pihak.

Dengan munculnya berbagai fenomena baru, menjadi nyata tantangan studi HI yaitu menjawab pertanyaan-pertanyaan baru dengan paradigma baru dan dalam konteks kurikulum artinya bagaimana kita menyajikan ilmu Hubungan Internasional secara berbobot, aktual dan menarik sehingga masyarakat atau penstudi HI mampu menghadapi dan mengantisipasi sejumlah tantangan global abad ini. ${ }^{5}$

\section{Indonesia di Tengah Globalisasi}

Pada intinya Globalisasi adalah keadaan dimana dunia semakin terintegrasi dan menyatu dalam berbagai segi dengan segala implikasi positif maupun negatifnya. Kecepatannya didorong oleh berkembangnnya teknologi, terutama teknologi komunikasi, sehingga perubahan yang ditimbulkannya pun semakin intens. Dengan demikian kita pun harus berpikir ulang mengenai keseluruhan posisi Indonesia dalam konteks ini. Dalam kerangka analisis SWOT,

${ }^{4}$ Lihat antara lain, Juwono Sudarsono, "State of the Art Hubungan Internasional: Mengkaji Ulang Teori Hubungan Internasional" dalam Perkembangan Studi Hubungan Internasional dan Tantangan Masa Depan. Jakarta: Pustaka Jaya, 1966. Hal 3-21. Lebih jauh mengenai Perang Dingin, dalam Charles S. Maier, ed. The Cold War in Europe: Era of a Divided Continent. Princeton: Markus Wiener Publishers, 1996. John Lewis Gaddis. The Cold War. London: Penguin Books. Ltd., 2005.

${ }^{5}$ Menurut pendapat Juwono Sudarsono, yang kiranya masih relevan, setidaknya ada 4 sorotan baru studi HI yang patut diperhatikan, yaitu (i) dalam era pasca perang dingin, perhatian pada usaha pemeliharaan persatuan dan kesatuan bangsa menghadapi lingkungan internasional yang kabur, tidak menentu dan kompetitif; (ii) keamanan regional; (iii) ekonomi politik internasional; (iv)three in one lingkungan hidup-hak asasi manusia-demokratisasi dan dampak globalisasi. Ibid., hal 13-14. Mengenai keragaman teoritis, lihat al. Asrudin dan Mirza Jaka Suryana, Refleksi Teori Hubungan Internasional dari Tradisional ke Kontemporer. Yogyakarta: Graha Ilmu, 2009. 
setidaknya kita bisa membuat analisis sederhana apa sebenarnya kekuatan, kelemahan, kesempatan dan ancaman yang relevan untuk "positioning" program studi Hubungan Internasional.

Bila mengacu pada analisis "kesempatan" saja, terutama dalam era globalisasi ini maka sudah pada tempatnya kalau kita memperkuat, memanfaatkan dan lebih menggali lagi kemungkinan keterlibatan Indonesia dalam lembaga regional dan internasional untuk kepentingan kita.

Sebagai ilustrasi pada tahun 2011 Indonesia mengetuai ASEAN dengan moto " ASEAN Community in a Global Community of Nations" dan pada tahun 2015 dicanangkan sebagai tahun sasaran terbentuknya Komunitas ASEAN. Kita tentu bisa bertanya "Apa peran Indonesia dalam mencapai tujuan Komunitas ASEAN 2015?" Sebagai lembaga pendidikan apa yang seharusnya kita siapkan untuk para penstudi HI khususnya dan kaum muda pada umumnya?

Indonesia bersama dengan beberapa negara berkembang lain (Afrika Selatan, Meksiko, Brazil, Argentina, India) telah masuk dan diperhitungkan dalam G-20, suatu kelompok negara-negara besar yang dianggap sangat berperan dalam menentukan keseimbangan hubungan ekonomi dunia. Apa yang dapat kita persiapkan dalam konteks studi Hubungan Internasional? Tentu pertanyaan serupa dapat kita ajukan dalam konteks keterlibatan Indonesia di forum regional dan internasional lain.

Dengan kata lain jika kita ingin menempatkan studi HI dalam konteks area geografis saja, maka fokus studi pada negara-negara yang paling dekat dengan Indonesia tidak dapat diabaikan, misalnya dengan negara anggota ASEAN, Australia, PNG, Timor Leste dan seterusnya mengikuti area lingkaran konsentris (concentric circle) Indonesia. Sejauh mana prioritas kawasan sesuai dengan lingkaran terdekat menjadi pusat perhatian penstudi HI dan dilakukan secara konsisten dan mendalam?

\section{Tabel 1. Analisis SWOT}

\begin{tabular}{|l|ll|}
\hline Kekuatan/Strength & - & Sumber daya alam \\
& - & $\begin{array}{l}\text { Demokrasi } \\
\text { - }\end{array}$ \\
& - & Multikultural \\
\hline Kelemahan/Weaknesses & - & $\begin{array}{l}\text { Kebijakan, Mindset } \\
\text { Penegakkan Hukum }\end{array}$ \\
\hline Kesempatan/Opportunities & - & $\begin{array}{l}\text { Keanggotaan dalam organisasi internasional } \\
\text { (regional dan multilateral: ASEAN, APEC, } \\
\text { NAM, OIC, UN, WTO. G-20, BWIs) }\end{array}$ \\
\hline
\end{tabular}

${ }^{6}$ Kerjasama Regional adalah kerja sama diplomatik dengan negara-negara di dunia internasional dalam seri lingkaran konsentris (concentric circles) yang terdiri dari: Lingkaran pertama adalah Association of Southeast Asian Nations (ASEAN) yang merupakan pilar utama bangsa Indonesia dalam menjalankan politik luar negerinya. Kemudian yang berada pada lingkaran konsentris kedua adalah ASEAN + 3 (Jepang, China, 


\begin{tabular}{|l|l|l|}
\hline Ancaman/Threats & - Cultural package \\
& - Terorisme \\
& - Konflik internal \\
\hline
\end{tabular}

\section{Lingkage Antar Sektor dan Lembaga}

Gejala integrasi yang semakin menguat di berbagai fungsi kelembagaan masyarakat lokal, nasional, regional maupun internasional mau tidak mau harus mengubah cara kerja dan "mindset" kita dalam berkiprah. Integrasi tidak memungkinkan masing-masing komponen berkerja sendiri demi keuntungan sendiri. Kata kunci baru harus kita adopsi yaitu "linkage" dan "sinergi". 7 Tidak ada sesuatu yang tidak berhubungan (link) dan tidak ada hasil yang maksimal tanpa sinergi. Perlu dicatat, dalam kultur tertentu, sinergi tidak selalu mudah

Korea Selatan). Di luar hal tersebut, Indonesia juga mengadakan hubungan kerja sama yang intensif dengan Amerika Serikat dan Uni Eropa yang merupakan partner utama ekonomi Indonesia. Dalam lingkaran konsentris yang ketiga, Indonesia mengakui pentingnya menggalang kerja sama dengan like-minded developing countries. Dengan forum-forum tersebut Indonesia dapat menerapkan diplomasinya untuk memperkuat usaha bersama dalam rangka menjembatani kesenjangan antara negara-negara berkembang dengan negara maju. Contoh kerjasama regional: ARF, BIMP-EAGA, IOR-ARC, MSG, ASEM, CICA, ACD, PIM, AMED, CTI, IMT-GT, SwPD, APEC, FEALAC, NAASP, Uni Eropa.

Sedangkan sasaran kerjasama Multilateral adalah meningkatnya peran aktif Indonesia dalam mewujudkan perdamaian dan keamanan internasional, pemajuan dan perlindungan HAM, kerjasama kemanusiaan serta meningkatnya pembangunan ekonomi, sosial budaya, keuangan, lingkungan hidup, perdagangan, perindustrian, investasi, komoditi, dan perlindungan hak kekayaan intelektual melalui penguatan kerjasama multilateral. Misalnya melalui OIC, G-15, PBB, WTO, G-20, WTO (Tourism), Colombo Plan,

GNB, G-8, G-77 dan China. Lih. http://www.kemlu.go.id/Pages/ IFP.aspx?P=Multilateral\&l=id

7 Linkage $(\mathrm{N})$ : connection: a relation between things or event; an association relation; the act of linking things together. http://www.thefreedictionary.com/linkage. Synergy may be defined as two or more things functioning together to produce a result not independently obtainable. In the context of organizational behavior, following the view that a cohesive group is more than the sum of its parts, synergy is the ability of a group to outperform even its best individual member. These conclusions are derived from the studies conducted by Jay Hall on a number of laboratory-based group ranking and prediction tasks. He found that effective groups actively looked for the points in which they disagreed and in consequence encouraged conflicts amongst the participants in the early stages of the discussion. In contrast, the ineffective groups felt a need to establish a common view quickly, used simple decision making methods such as averaging, and focused on completing the task rather than on finding solutions they could agree on. http://en.wikipedia.org/wiki/Synergy. (i) The interaction of two or more agents or forces so that their combined effect is greater than the sum of their individual effects. (ii) Cooperative interaction among groups, especially among the acquired subsidiaries or merged parts of a corporation, that creates an enhanced combined effect. http://www.answers.com/topic/synergy\#ixzz1d1Fq802O 
karena berbagai faktor ego sektoral, kelompok atau pun golongan. Untuk itu diperlukan selain waktu juga revolusi "radikal" untuk mencapai "mindset" baru.

Jika masyarakat kita gambarkan secara sederhana dalam tiga (3) sektor utama, yaitu Pemerintah, Bisnis/Korporasi dan Masyarakat Sipil/Madani, maka "linkage" (kaitan) tersebut terjadi meskipun fungsi pokok masing-masing berbeda karena kepentingannya memang berbeda dengan dasar nilai yang berbeda tetapi tidak boleh saling merugikan. Jika pemerintah lebih berfungsi sebagai fasilitator fungsi usaha/produksi dan kesejahteraan masyarakat sipil, dunia usaha pada fungsi produksi dan profit, maka masyarakat sipil adalah lebih pada kesejahteraan sosial.

\section{Skema 2. Linkage antar Sektor}

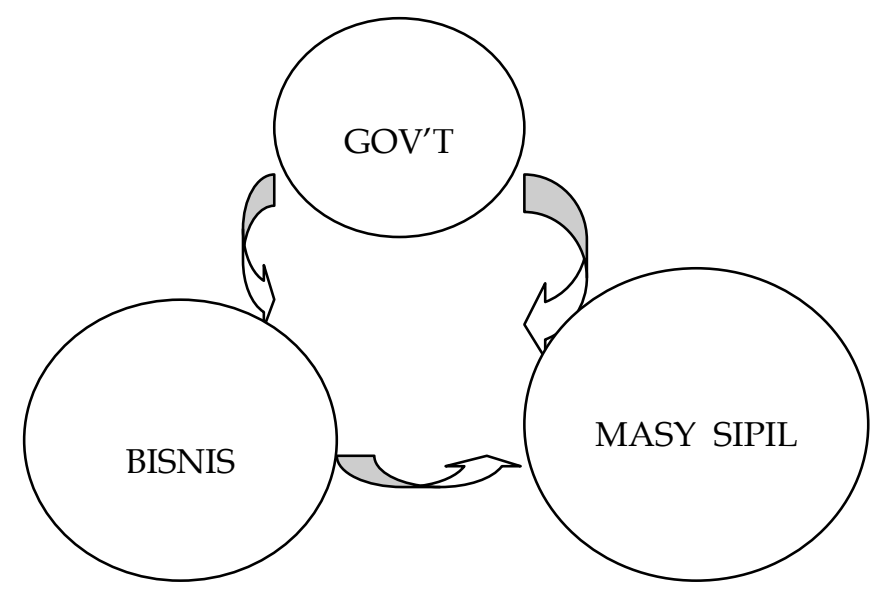

Dengan melihat peluang berkiprah (berprofesi) para lulusan Hubungan Internasional, maka pengetahuan mengenai bagaimana logika Pemerintah, Bisnis dan Masyarakat Sipil bekerja adalah amat penting, sekaligus juga bagaimana ketiga area tersebut saling berhubungan dan melakukan "linkage" akan menjadi dasar untuk masuk dunia kerja.

Mata kuliah yang berkaitan dengan operasionalisasi ketiga sektor tersebut menjadi penting diperkenalkan sekaligus sebagai pijakan bagi studi lanjutan maupun masuk dunia kerja. Dari sektor Pemerintahan, pengetahuan mengenai struktur kelembagaan/fungsi/kewenangan, peran dan tugas Kementrian Luar Negeri, Kebijakan dan Politik Luar Negeri, Diplomasi, peran Negara dan sebagainya menjadi pengetahuan dasar. Dari sektor bisnis, pengetahuan mengenai lingkungan Bisnis Internasional, Ekonomi Politik, Manajemen Internasional, Ekonomi Makro, Geoekonomi, akan sangat membantu penstudi HI memahami fenomena yang terus muncul, mis krisis ekonomi, fluktuasi pasar modal dan sebagainya. Sedangkan untuk sektor masyarakat madani pengetahuan akan organisasi internasional, kemiskinan, gerakan sipil, perlawanan kolektif (collective 
action), kekuatan global, lingkungan, jender, pemberdayaan (empowerment) dan sebagainya akan sangat memperluas perspektif dalam melihat persoalan dunia nyata.

\section{Orientasi Dunia Kerja}

Mengingat pendidikan Universitas tidak dapat lagi berada "di menara gading" melainkan harus aplikatif dan dapat menjawab persoalan masyarakatnya, maka kemampuan lulusan HI untuk melakukan "linkage" sangat penting, karena dimanapun lulusan HI nanti bekerja baik di pemerintahan, perusahaan maupun lembaga swadaya dia harus mampu "membaca" dan "melakukan" linkage: yaitu membangun dan mengaplikasikan berbagai hubungan (link) dengan partnernya. Sebagai contoh:

- Seseorang yang bekerja di Perusahaan Bisnis dan kebetulan mengembangkan departemen CSR (Corporate Social Responsibility), maka dia harus mampu me "link" dengan komunitas lokal (masyarakat sipil) dan mampu berkomunikasi dengan komunitas lokal maupun manajemen korporasinya. Dia pun harus mengetahui peraturan daerah dimana proyeknya bekerja dan siapa yang menjadi partnernya apakah tingkat lurah, camat, pemerintah daerah, dsbnya. Dengan kata lain pengetahuan mengenai Pemerintah, Korporasi dan Masyarakat Sipil sangat diperlukan karena semua pihak itu adalah para pemangku kepentingan program yang dilaksanakan;

- Seseorang yang bekerja untuk FAO-UN biasanya dia harus melaksanakan proyek yang berkaitan dengan lembaga keuangan Internasional yang mendanai proyek tersebut (mis ADB, IMF) dan dengan pemerintah di lokasi proyek (mis Indonesia, Thailand) termasuk pemerintah daerahnya, sekaligus melakukan pelaporan dan komunikasi untuk beberapa pihak (UN, ADB, GOI) serta stakeholder lainnya misalnya Asosiasi Profesi (Perkebunan, Pertanian, Komoditi tertentu). Pengetahuan mengenai berbagai partner yang berbeda ini akan sangat membantu, karena logika dan kepentingan mereka yang berlainan juga harus dipahami.

\section{Pembekalan Soft Skill dan Hard Skill ${ }^{8}$}

8 Soft skills, sometimes known as "people skills," are personal attributes that enhance an individual's interactions, job performance and career prospects. Unlike hard $\underline{\text { skills, }}$, which tend to be specific to a certain type of task or activity, soft skills are broadly applicable. Soft skills are sometimes broken down into personal attributes, such as: optimism, common sense, responsibility, a sense humor, integrity, time-management, motivation, and interpersonal abilities, such as: empathy, leadership, communication, good manners, sociability, the ability to teach. Lih. http://www.hiringsolutions.net/ Content/softHardSkills.html. 
Apakah lulusan HI hanya berkutat dengan konsep-konsep dan teori-teori saja? Melihat konteks di atas tentunya tidaklah demikian. Ada berbagai bidang kerja dan profesi yang sangat terbuka bagi para lulusan HI. Meskipun untuk kasus Indonesia perlu diperkuat dengan data Tracer Study, namun berbagai bidang pekerjaan dan karir terbuka bagi lulusan $\mathrm{HI}$, antara lain:

Tabel 3. Bidang Pekerjaan Lulusan Studi HI ${ }^{9}$

\begin{tabular}{|c|c|c|}
\hline Bidang & Karakteristik Umum & Persyaratan \\
\hline $\begin{array}{l}\text { Pemerintahan dan } \\
\text { Diplomasi }\end{array}$ & $\begin{array}{l}\text { Pekerjaan-pekerjaan di bidang } \\
\text { ini menawarkan kesempatan } \\
\text { untuk ikut mempengaruhi } \\
\text { kebijakan, tetapi } \\
\text { membutuhkan kesabaran } \\
\text { yang tinggi berhadapan } \\
\text { dengan birokrasi besar. }\end{array}$ & $\begin{array}{l}\text { Fleksibel dan bersedia } \\
\text { bekerja di bidang yang } \\
\text { tidak sama dengan } \\
\text { minat si pekerja } \\
\text { - Terampil dan mampu } \\
\text { bekerja dalam } \\
\text { kelompok } \\
\text { - Mampu membangun } \\
\text { dan memiliki jejaring } \\
\text { yang luas } \\
\text { Terampil berbahasa } \\
\text { asing } \\
\text { Memiliki daya analisa } \\
\text { kuat } \\
\text { Terampil menulis }\end{array}$ \\
\hline Bisnis Internasional & $\begin{array}{l}\text { Pekerjaan-pekerjaan di bidang } \\
\text { ini menawarkan kesempatan } \\
\text { untuk mendapatkan } \\
\text { penghasilan tinggi dan } \\
\text { pekerjaan menarik, tetapi } \\
\text { menuntut kesediaan bekerja } \\
\text { dalam tekanan waktu dan } \\
\text { ketrampilan berbahasa asing } \\
\text { maupun ketrampilan lintas } \\
\text { budaya yang sangat prima. }\end{array}$ & $\begin{array}{l}\text { - Memiliki cross-cultural } \\
\text { skills } \\
\text { - } \text { Terampil berbahasa } \\
\text { asing } \\
\text { - Memiliki ketrampilan } \\
\text { standar bisnis } \\
\text { - Memiliki daya analisa } \\
\text { kuat } \\
\text { - Terampil menulis } \\
\text { - Memahami penelitian }\end{array}$ \\
\hline $\begin{array}{l}\text { Organisasi } \\
\text { Pemerintah }\end{array}$ & $\begin{array}{l}\text { Pekerjaan-pekerjaan di bidang } \\
\text { ini memberikan kepuasan } \\
\text { pribadi bagi mereka yang } \\
\text { ingin terlibat langsung dalam } \\
\text { pengembangan masyarakat, } \\
\text { tetapi selain tidak } \\
\text { menawarkan penghasilan } \\
\text { yang besar juga menuntut }\end{array}$ & $\begin{array}{l}\text { - Mampu bekerja mandiri } \\
\text { (self-starter) } \\
\text { - Bersedia sebagai } \\
\text { volunteer untuk jangka } \\
\text { waktu tertentu } \\
\text { - Menguasai ketrampilan } \\
\text { dasar perkantoran } \\
\text { - Terampil menulis dan }\end{array}$ \\
\hline
\end{tabular}

9 Diambil dari Edwin Tambunan, “Mengindonesiakan Studi Hubungan Internasional", dalam Verity, Jurnal Hubungan Internasional UPH Tahun 1, Nomor 2, JuliDesember 2009 hal 88-89. 


\begin{tabular}{|c|c|c|}
\hline & $\begin{array}{l}\text { pengorbanan pribadi dalam } \\
\text { melakukannya. }\end{array}$ & $\begin{array}{l}\text { berkomunikasi } \\
\text { - Terampil berbahasa } \\
\text { asing }\end{array}$ \\
\hline $\begin{array}{ll}\text { Pendidikan } & \text { dan } \\
\text { Penelitian } & \end{array}$ & $\begin{array}{l}\text { Pekerjaan-pekerjaan di bidang } \\
\text { ini menawarkan kebebasan } \\
\text { berpikir dan kesempatan } \\
\text { untuk menyebarluaskan } \\
\text { gagasan-gagasan kita, tetapi } \\
\text { membutuhkan waktu dan } \\
\text { studi yang cukup panjang } \\
\text { untuk bisa memasukinya. }\end{array}$ & $\begin{array}{l}\text { - Memiliki kemampuan } \\
\text { berpikir kritis } \\
\text { - Terampil } \\
\text { menyampaikan gagasan } \\
\text { secara lisan maupun } \\
\text { tertulis } \\
\text { - Terampil melakukan } \\
\text { penelitian } \\
\text { menggunakan } \\
\text { methodological toolbox } \\
\text { yang ada } \\
\text { - Terampil berbahasa } \\
\text { asing. }\end{array}$ \\
\hline
\end{tabular}

Untuk memasuki berbagai bidang pekerjaan di atas, ada berbagai ketrampilan (Soft skill dan Hard Skill) pokok yang harus dikuasai agar siap masuk dunia kerja, yaitu:

\section{Tabel 4. Soft Skill dan Hard Skill}

\begin{tabular}{|c|c|}
\hline - Komunikasi & $\begin{array}{l}\text { Office/Executive, Public Relations, } \\
\text { International Meeting/Conference }\end{array}$ \\
\hline - $\quad$ Manajemen & Office, Project \\
\hline - Linkage & $\begin{array}{l}\text { Bagaimana menciptakan linkage/hubungan } \\
\text { dengan berbagai pihak yang potensial. }\end{array}$ \\
\hline - $\quad$ Presentasi & Proyek, proposal, marketing, atau laporan \\
\hline - Pelaporan/Reporting & Harian atau proyek keseluruhan, field report \\
\hline - $\quad$ Bahasa Asing & $\begin{array}{l}\text { Inggris, Mandarin, bahasa negara Asia lain } \\
\text { (Thailand, Filipina); bahasa yang digunakan } \\
\text { dalam forum PBB, UE }\end{array}$ \\
\hline
\end{tabular}


Penguasaan Soft skill bisa dilaksanakan melalui:

Tabel 5. Metode Penguasaan Ketrampilan

\begin{tabular}{|c|c|}
\hline - $\quad$ Short Course & $\begin{array}{l}\text { - Modul disiapkan bekerjasama } \\
\text { dengan praktisi mis praktisi PR, } \\
\text { Manajemen dari } \\
\text { lembaga/perusahaan Internasional } \\
\text { atau mantan Diplomat karier untuk } \\
\text { bidang diplomasi/kerjasama } \\
\text { internasional. }\end{array}$ \\
\hline $\begin{array}{l}\text { Exposure (Kunjungan } \\
\text { Lapangan melihat } \\
\text { langsung operasional } \\
\text { suatu } \\
\text { organisasi/korporasi) }\end{array}$ & $\begin{array}{l}\text { - Kunjungan ke Lembaga } \\
\text { Internasional seperti UN, ASEAN, } \\
\text { Kedutaan Asing, Human Rights } \\
\text { Watch, dll', atau kunjungan ke } \\
\text { negara lain dengan tujuan spesifik } \\
\text { melihat keunggulan di bidang } \\
\text { tertentu. }\end{array}$ \\
\hline - $\quad$ Internship (magang) & $\begin{array}{l}\text { - Kementrian LN, Kedutaan Asing, } \\
\text { Lembaga Studi/Think Tank } \\
\text { - } \quad \text { Di Lembaga Internasional (UN- } \\
\text { FAO, WHO, ILO; INGO; dsb) } \\
\text { - Korporasi (Microsoft, Oil Company, } \\
\text { dll) }\end{array}$ \\
\hline
\end{tabular}

\section{Penutup}

Masyarakat antar bangsa tidak pernah statis atau berhenti bergerak. Sebagai obyek studi Hubungan Internasional atau Studi Kawasan, hal ini berimplikasi dalam cara kita menyikapinya sebagai bagian dari masyarakat penstudi Hubungan Internasional. Bagaimanapun juga "mindset" kita juga harus dinamis, dengan selalu mengikuti perkembangan yang ada dan yang penting selalu terbuka dengan berbagai perubahan dan sudut pandang.

Satu hal yang lebih penting adalah studi Hubungan Internasional berkembang pesat dan akan semakin melibatkan berbagai disiplin yang lain sehingga penstudi Hubungan Internsional harus bergerak dari tingkat "dasar" ke tingkat lebih tinggi atau "lanjut" dengan memanfaatkan berbagai peralatan konseptual yang relevan untuk melakukan analisis hubungan internasional kontemporer. Peralatan konseptual tersedia di berbagai disiplin ilmu sosial yang lain, sehingga terus menerus mengikuti disiplin yang lain menjadi bagian dari memperkuat karakter interdisipliner dalam HI. 
Harapan selanjutnya, ranah pengembangan Hubungan Internasional di Indonesia diharapkan bisa berkembang lebih jauh menjadi Ilmu Hubungan Internasional transformatif - tidak sekedar berhenti pada derajat sintaksis (ketepatan menyampaikan informasi, sekedar mentransfer dan memproses informasi secara apa adanya, sekedar meniru tanpa hirau persoalan metodologis) dalam model pembelajarannya atau semantik (lebih berani menafsir atau memahami makna tersirat, dengan resiko salah atau menghasilkan pengetahuan baru) saja - tetapi suatu aktualisasi ilmu sosial yang bertanggungjawab ditandai dengan kemampuan mengambil manfaat berdasarkan kebutuhan yang jelas dan pada saat yang sama paham, fasih dalam menghayati dan menerapkan metodologi yang tersedia. Juga berdasarkan kesadaran konteks dan pemahaman akan berbagai peluang yang terbuka, terus menerus terlibat dalam upaya memajukan ilmu pengetahuan. ${ }^{10}$

\section{Daftar Pustaka}

\section{Buku}

Asrudin dan Mirza Jaka Suryana, dkk. 2009. Refleksi Teori Hubungan Internasional dari Tradisi ke Kontemporer.Yogyakarta: Graha Ilmu.

Bretton, Gilles and Michael Lambert (Ed.). 2003. Universities and Globalization: Private Linkages, Public Trust. Paris: the United Nations Educational, Scientific and Cultural Organization.

Gaddis, John Lewis. 2005. The Cold War. London: Penguin Books. Ltd.

Jackson, Robert and Georg Sorensen. 2009. Pengantar Studi Hubungan Internasional. Yogyakarta: Pustaka Pelajar.

Maier, Charles, S. 1996. The Cold War in Europe: Era of a Divided Continent. Princeton: Markus Weiner Publishers.

Maso'ed, Mohtar 1990. Ilmu Hubungan Internasional Disiplin dan Metodologi. Jakarta: Penerbit LP3ES.

Sitepu. Anthonius P. 2011. Studi Hubungan Internasional. Yogyakarta: Graha Ilmu.

Santoso, Purwo. 2011. "Ilmu Sosial Transformatif". Pidato Pengukuhan Jabatan Guru Besar pada Fakultas Ilmu Sosial dan Ilmu Politik Universitas Gadjah Mada. Yogyakarta.

10 Lebih jauh lihat dalam "Ilmu Sosial Transformatif”. Pidato Pengukuhan Jabatan Guru Besar Prof. Dr. Purwo Santoso, M.A., Ph.D pada Fakultas Ilmu Sosial dan Ilmu Politik Universitas Gadjah Mada. Diucapkan di depan rapat Terbuka Majelis Guru Besar UGM pada 19 April 2011 di Yogyakarta. Suatu Pidato yang amat memberikan inspirasi, menyadarkan akan tanggungjawab pengembangan ilmu sosial pada umumnya terutama mengenai politik pengembangan ilmu yang tidak hanya bergantung pada negara maju tetapi sebagai bagian dari keharusan dan komitmen ilmuwan Indonesia mengatasi persoalan bangsanya dan sebagai sumber pengembangan ilmu. 
Soeprapto. 1997. Hubungan Internasional: Sistem, Interaksi dan Perilaku. Jakarta: PT RajaGrafindo Persada.

Sudarsono. Juwono dkk. 1996. Perkembangan Studi Hubungan Internasional dan Tantangan Masa Depan. Jakarta: Pustaka Jaya.

Williams, Phil, Donald M. Goldstein and Jay M. Shafritz. 2006. Classic Readings and Contemporary Debates in International Relations. Belmont, CA: Thomson Wadsworth.

\section{Jurnal}

Tambunan. Edwin, MB. 2009. “Mengidonesiakan Studi Hubungan Internasional Melalui Rekonstruksi Kurikulum", dalam Verity Jurnal Hubungan Internasional, Tahun 1, Nomor 2, Juli-Desember 2009. Hal 83-91.

\section{Media}

"Ilmuwan Indonesia Diincar. Anggaran Penelitian Cuma Sekitar 0,3 Persen dari APBN". Kompas, 24 Oktober 2011

“Negeri ini Tidak Nyaman bagi Peneliti”. Kompas, 24 Oktober 2011.

“Potensi yang Terlalaikan”. Tajuk Rencana. Kompas 25 Oktober 2011.

“Kesejahteraan Ilmuwan: Tak Ada Rencana Naikkan Gaji Peneliti”. Kompas, 27 Oktober 2011.

"Culture of Bullying Grips Jakarta School". The Jakarta Post, October 28, 2011.

“RI's Education Development Index Drops". The Jakarta Post, October 31, 2011

"Key Problem of Education in RI: Teacher Centralization. The Jakarta Post, October 31, 2011.

\section{Website}

http://www.hiringsolutions.net/Content/softHardSkills.html.

http://www.answers.com/topic/synergy\#ixzz1d1Fq802O

http://en.wikipedia.org/wiki/Synergy.

http://www.thefreedictionary.com/linkage.

http://www.kemlu.go.id/Pages/IFP.aspx?P=Multilateral\&l=id

http://en.wikipedia.org/wiki/Jeremy_Bentham

http://en.wikipedia.org/wiki/International_relations 